\title{
Stress and cortisol levels among members of the nursing team
}

\author{
Estresse e níveis de cortisol capilar entre a equipe de enfermagem \\ Niveles de estrés y cortisol entre miembros del equipo de enfermería
}

Vanessa Augusto Bardaquim' ORCID: 0000-0003-2179-552X

Sérgio Valverde Marques dos Santos' ORCID: 0000-0001-9412-9515

Ernandes Gonçalves Dias' ORCID: 0000-0003-4126-9383

Rita de Cássia de Marchi Barcellos Dalri' ORCID: 0000-0002-6575-5426

Aida Maria de Oliveira Cruz Mendes" ORCID: 0000-0002-1992-9632

Maria Cecília Gallani"I ORCID: 0000-0002-3418-9134

Maria Lúcia do Carmo Cruz Robazzi' ORCID: 0000-0003-2364-5787

'Universidade de São Paulo. Ribeirão Preto, São Paulo, Brazil. "Escola Superior de Enfermagem de Coimbra. Coimbra, Portugal.

II' Universidade Laval. Quebec, Canada.

How to cite this article: Bardaquim VA, Santos SVM, Dias EG, Dalri RCMB Mendes AMOC, Gallani MC, et al. Stress and cortisol levels among members of the nursing team.

Rev Bras Enferm. 2020;73(Suppl 1):e20180953. doi: http://dx.doi.org/10.1590/0034-7167-2018-0953

\section{Corresponding author:}

Vanessa Augusto Bardaquim

E-mail:va.bardaquim@bol.com.br

EDITOR IN CHIEF: Dulce Aparecida Barbosa ASSOCIATE EDITOR: Antonio José de Almeida Filho

Approval: 09-02-2019

\section{ABSTRACT}

Objective: To analyze the characteristics of hospital nursing professionals with the presence of stress, and to associate this with capillary cortisol. Method: A cross-sectional, exploratory and correlational study, conducted in a hospital in São Paulo, Brazil. A total of 164 nursing professionals participated; the Perceived Stress Scale was administered, and hair samples were obtained for laboratory analysis. Data were entered into a Microsoft Excel spreadsheet (2010), and then into Microsoft Office and the R software, version 3.2.2. Results: High levels of capillary cortisol in $47 \%$ of participants suggest the presence of stress, but no statistical significance between cortisol and stress levels were found. Conclusions: Stress and capillary cortisol levels were indicative of stress among nursing professionals; however, no association between them was found, although the values found were above those recommended. Descriptors: Hydrocortisone; Nursing Service, Hospital; Occupational Stress; Occupational Health; Nursing, Team

\section{RESUMO}

Objetivo: Analisar características de trabalhadores de enfermagem da área hospitalar com a presença de estresse e associar com o cortisol capilar. Método: Estudo de corte transversal, exploratório e correlacional, realizado em um hospital paulista, Brasil. Participaram 164 trabalhadores de enfermagem, nos quais foi aplicada a Perceived Stress Scale e obtidas amostras de cabelos para análise laboratorial. Os dados foram inseridos em planilha do MSExcel (2010) e, após, no programa Microsoft Office e no software R, versão 3.2.2. Resultados: Elevados níveis de cortisol capilar em $47 \%$ dos participantes sugerem a presença de estresse, mas não houve significância estatística entre níveis de cortisol e de estresse. Conclusões: níveis de estresse e de cortisol capilar foram indicativos de presença de estresse entre trabalhadores de enfermagem; entretanto, não houve associação entre eles, embora estivessem acima dos recomendados.

Descritores: Hidrocortisona; Serviço Hospitalar de Enfermagem; Estresse Ocupacional; Saúde do Trabalhador; Equipe de Enfermagem.

\section{RESUMEN}

Objetivo: analizar las características de los trabajadores de enfermería hospitalarios con presencia de estrés y asociarlos con el cortisol capilar. Método: estudio transversal, exploratorio y correlacional, realizado en un hospital de São Paulo, Brasil. Participó un total de 164 trabajadores de enfermería, a quienes se aplicó la Escala de estrés percibido y se obtuvieron muestras de cabello para análisis de laboratorio. Los datos se ingresaron en una hoja de cálculo MS-Excel (2010) y luego en el software Microsoft Office and R, versión 3.2.2. Resultados: altos niveles de cortisol capilar en el $47 \%$ de los participantes sugieren la presencia de estrés, pero no hubo relevancia estadística entre los niveles de cortisol y el estrés. Conclusiones: el estrés y los niveles de cortisol capilar fueron indicativos de estrés entre los trabajadores de enfermería; sin embargo, no hubo asociación entre ellos, aunque estaban por encima de los recomendados. Descriptores: Hidrocortisona; Servicio de Enfermería en Hospital; Estrés Laboral; Salud Laboral; Grupo de Enfermería. 


\section{INTRODUCTION}

Psychosocial factors can affect professionals' health by means of psychological and physiological mechanisms, due to the interaction between work, professionals, environment, job satisfaction, and organizational conditions, which can also be described as psychophysical, psychophysiological, or psychoergonomic interactions ${ }^{(1)}$.

Stress arising from work environments and the manner in which the work is organized affects many professionals; in the health area, nursing professionals are one of the groups that suffer most from stressful situations ${ }^{(2)}$. The stress among these Brazilian workers has been repeatedly proven ${ }^{(3-4)}$. Psychosocial stressors are as efficient of causing disease as the unhealthiness of microorganisms present in the environment; inadequate and tense working conditions that occur during the nursing work, such as prolonging working hours, facilitating the emergence of stressors in occupational environments ${ }^{(5)}$.

Nursing professionals' show a high level of responsibility and low autonomy, which reflect stress and stress points ${ }^{(6)}$. The most common stressors present in nursing work environments are related to working conditions and processes ${ }^{(7)}$.

In stressful conditions, the physiology of the body leads to the secretion of a large amount of cortisol(8), which is considered one of its central hormones ${ }^{(9)}$. It is the main endogenous human glucocorticoid (GC) secreted in response to adrenocorticotropic hormone $(\mathrm{ACTH})^{(10)}$, released by the pituitary-adrenal hypothalamic axis (HPA) ${ }^{(11)}$. The link between occupational stress, physical and mental health, and one of the pathways that potentially mediate these associations may involve the HPA axis, with this GC used as the final metabolite ${ }^{(12)}$. Long-term changes in the activity of this axis have shown that cortisol accumulates in the capillary wire ${ }^{(13)}$, and can be considered a biomarker of chronic stress ${ }^{(14)}$.

Measuring cortisol levels in hair is a recently developed method for measuring long-term GC levels ${ }^{(15)}$. While salivary and urine cortisol show the levels in real time, capillary cortisol analysis provides a complementary methods of monitoring stress, identifying systemic exposure to this GC for longer periods ${ }^{(16)}$. In contrast to "spot samples" obtained from plasma or saliva, obtaining hair samples provides an integrated measure of HPA system activity and, therefore, physiological stress during the period of hormonal incorporation. It can provide a retrospective measure of systemic cortisol secretion during the corresponding hair growth time ${ }^{(17)}$.

Based on this context, given the possibility of cortisol obtained from the hair being considered a biomarker for measuring stress, in addition to the fact that nursing professionals are a group prone to stress at work, the importance of assessing cortisol levels among them is justified. Given this context, conducting the present study is justified, as it is expected to add to existing knowledge about the health of nursing professionals working in the hospital environment.

Thus, the following guiding question was developed: Are the cortisol levels obtained from the hair of nursing professionals related to the presence of stress and the characteristics of the work performed by them?

\section{OBJECTIVE}

To analyze the characteristics of the work performed by nursing professionals with the presence of stress, and to correlate this with capillary cortisol values.

\section{METHODS}

\section{Ethical aspects}

Based on Resolution 466 of 2012, this study was approved by the Research Ethics Committee.

\section{Design, period and place of study}

This was a cross-sectional, exploratory, quantitative correlational research study. The data collection was performed at a medium-sized hospital in the interior of São Paulo State, Brazil, between January and March of 2017.

\section{Population and inclusion criteria}

The population of this study consisted of 164 members of the nursing staff, represented by nurses, nursing technicians, and auxiliaries.

Professionals of both sexes, working in the following sectors were included: isolation (I), adult intensive care unit (ICU), adult coronary care unit (CCU), urgent care and emergency (UC/ER) and the medical clinic (MC). Those who were not found at the time of data collection were excluded, for any reasons of absence from work, including illness, accidents, vacation or time off.

The sample was obtained by using the stratified random sampling method, with proportional allocation by strata, formed by the ICU, CCU, UC/E, I, and MC sectors. Since the prevalence of the variables of interest in the target population was unknown, the criterion used recommended relative error parameters of 20, significance level of $5 \%$, and a prevalence of $50 \%$ in each stratum $^{(18)}$. Thus, in the end, 164 nursing workers became participants.

\section{Study Protocol}

In this study there was no control group; comparative analyses of the normal values of capillary cortisol were obtained by means of the median made between the sectors participants.

Data collection consisted of obtaining strands of hair and administering the instruments, during the work hours of the participants, on the morning, evening, and night shifts. Each participant underwent hair sampling and questionnaires, performed on the same day.

The instruments were administered in a private, air-conditioned room; participants were seated, and responded to self-administered instruments. The first author stayed by their side to answer questions, and to avoid communication between the respondents, and then to obtain the strands of hair.

Two instruments were used. The first was a personal and work characteristics questionnaire, adapted and developed in Brazil, and already used for this type of population ${ }^{(19)}$, consisting of 19 structured and semi-structured questions, directed to 
the variables that aim to identify the worker, as well as his/her professional activity.

The second instrument was the Perceived Stress Scale (PSS), which measures stress among professionals. This scale measures the degree of perceived stress of individuals during the month prior to the assessment ${ }^{(20)}$. It has 14 questions, with options for answers ranging from zero to four $(0=$ never; $1=$ almost never; $2=$ =sometimes; $3=$ almost always; $4=$ always), with questions having both positive and negative connotations. The total scale is obtained from the sum of the scores of these 14 questions, and the scores may vary from 0 to 56 ; the higher the scores, the higher the perceived stress ${ }^{(20)}$. The results of the validation of the scale for Brazilian Portuguese were satisfactory, with an internal consistency of $r=0.82$ and were effective to detect differences between groups ${ }^{(21)}$. The cutoff point was adopted with five (5) scoring intervals: $\leq 18$ (low), 19-24 (normal), 25-29 (moderate), 30-35 (high), and >35 (very high) ${ }^{(22)}$. In this study, when assessing the internal consistency of the scale, the Cronbach's alpha coefficient obtained a value of 0.870 .

To measure cortisol levels after hair collection, we followed the instructions contained in the specific saliva Cortisol ELISA (EnzymeLinked Immunosorbent Assay) kit (KAPDB290), but validated for hair samples used in other studies ${ }^{(15,23-24)}$. The ELISA method has advantages over the others, has good sensitivity, and favors fast results ${ }^{(25)}$.

A total of 164 hair samples were obtained for capillary cortisol measurement; the hair samples were cut with surgical scissors on the posterior vertex region of the head, as close as possible to the root, because it is the area with the lowest growth rate variability, and has the highest concentration of cortisol $^{(26)}$.

A lock of hair (about $0.5 \mathrm{~cm}$ ) was separated, two centimeters (cm) below the base of the skull. In some cases, hair had to be cut at different locations in the same region, to obtain the same amount. According to recommendations, strands of $3 \mathrm{~cm}$ in length were obtained ${ }^{(26-27)}$.

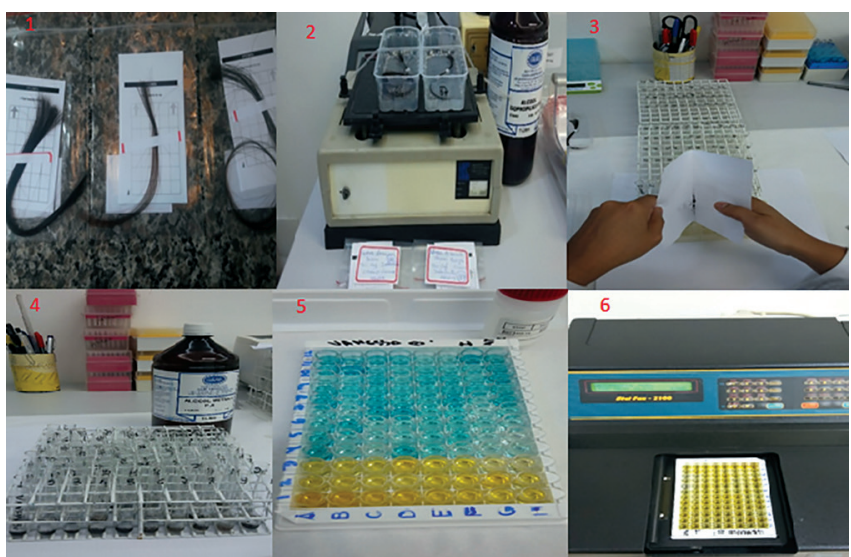

Subtitle: 1. Separation of hair samples; 2.washing of samples; 3 . cutting; 4. addition of isopropyl alcohol; 5 . addition of chemical reagents; 6 . time to read the plates.

Figure 1 - Laboratory steps performed for capillary cortisol extraction and measurement among hospital nursing professionals, 2017

The width of the strand was to be one (1) cm; an amount corresponding to at least 30 milligrams $(\mathrm{mg})$ of hair per participant was obtained. The samples were then packed in specific envelopes and boxes to prevent contamination; afterwards, they were sent to a laboratory specialized in clinical evaluations for capillary cortisol analysis. The reference values used in this study were those of the clinical analysis laboratory ${ }^{(24)}$ where the method for extracting capillary cortisol was similar to that of the present study. The values considered were: below normal cortisol - up to 16 picograms of cortisol/milligrams of hair ( $\mathrm{pg} / \mathrm{mg})$, normal - 16 to $84 \mathrm{pg} / \mathrm{mg}$, and above normal values - > $84 \mathrm{pg} / \mathrm{mg}$.

The laboratory steps performed in the present study are shown in Figure 1.

\section{Results analysis and statistics}

The collected data were entered into an Excel spreadsheet, version 2010, to develop the database. Subsequently, double entry was performed to avoid transcription errors. For descriptive and inferential statistical analysis, the R software, version 3.2.2, was used. The Pearson chi-square, Kruskal-Wallis non-parametric hypothesis, Spearman correlation coefficient, and Mann-Whitney tests were performed, to verify possible relationships between the characteristic variables, stress, and capillary cortisol.

\section{RESULTS}

Descriptive analysis of the personal characteristics of the surveyed workers showed that, of the 164 participants: 132 (80.5\%) were female; aged 30 - 39 years (41.5\%) and 19 - 29 years (25.6\%). Single, separated/divorced/widowed respondents accounted for 88 (53.7\%); 76 (46.3\%) were married/living with a partner.

Regarding work-related aspects, the prevalence of nursing technicians (102-62.2\%) was identified, followed by nurses (35$21.3 \%)$, and nursing auxiliaries (27-16.5\%); all the respondents were permanent employees (100\%). Regarding the number of employment relationships, 139 (84.8\%) held only one job, and 25 (15.2\%) had two. Regarding the number of jobs in another area, other than nursing: 154 (93.9\%) answered that they did not have another job, and nine (5.5\%) worked in other types of jobs, and one person did not respond. With regard to the work shift, 86 participants (52.4\%) worked during the day, 70 at night (42.7\%) and only eight (4.9\%) worked both shifts; 154 (93.9\%) were still working on weekends. Regarding the sectors of work, 79 (48.2\%) worked in the MC, followed by the ER/UC with 34 (20.7\%), CCU with 24 (14.6\%), adult ICU with 21 (12.8\%), and six $(3.7 \%)$ in the isolation unit.

Table 1 presents the classification of perceived stress among nursing professionals, according to the cutoff point established ${ }^{(22)}$.

Table 2 describes the levels of cortisol present in the participants' hair. For the biological analysis of capillary cortisol, 161 participants were included, due to lack of material from three of them.

Almost half of the professionals (47\%) had cortisol levels above the established level, indicating the presence of stress. However, 13.4\% were below these levels (Table 2 ).

Table 3 shows the analysis of the correlation of the cortisol variable with perceived stress, age, work time, and sector of professional activity; with regard to the stress variable, correlations were obtained with age, professional performance, employment in nursing and non-nursing, professional category, and employment sector.

None of the variables analyzed (Table 3 ) showed a significant relationship with stress and cortisol; there was no significant relationship between stress and cortisol ( $p>0.05)$. 
Table 1 - Classification of the variable, perceived stress, among nursing staff in the hospital context, Sao Paulo, Brazil, 2017 ( $N=164$ )

\begin{tabular}{lccc}
\hline Classification & Interval & f & \% \\
\hline Low & $<=18$ & 35 & 21.3 \\
Normal & $19-24$ & 36 & 22 \\
Moderate & $25-29$ & 39 & 23.8 \\
High & $30-35$ & 33 & 20.1 \\
Very high & $>35$ & 21 & 12.8 \\
\hline
\end{tabular}

Table 2 - Capillary cortisol levels among nursing staff in the hospital context, Sao Paulo, Brazil, $2017(n=161)$

\begin{tabular}{lcc}
\hline Level & $\mathbf{f}$ & $\%$ \\
\hline Low & 22 & 13.4 \\
Normal & 62 & 37.8 \\
High & 77 & 47.0 \\
Total & 161 & 98.2 \\
Not analyzed & 3 & 1.8 \\
Total & 161 & 100.0 \\
\hline
\end{tabular}

Table 3 - Correlation tests of cortisol and stress variables with those related to work among nursing professionals in the hospital context, Sao Paulo, Brazil, $2017(n=161)$

\begin{tabular}{llc}
\hline Variable 1 & Variable 2 & $\boldsymbol{p}$ value \\
\hline Cortisol & Perceived stress & $0.1043^{*}$ \\
Cortisol & Age & $0.9484^{*}$ \\
Cortisol & Work time & $0.4619^{*}$ \\
Cortisol & Professional category & $0.8526^{* *}$ \\
Cortisol & Sector of acting & $0.0875^{* * *}$ \\
Stress & Age & $0.295^{*}$ \\
Stress & Practice in the profession & $0.4864^{*}$ \\
Stress & Job in nursing & $0.5671^{*}$ \\
Stress & Job outside nursing & $0.4304^{*}$ \\
Stress & Professional category & $0.3113^{* *}$ \\
Stress & Employment sector & $0.9535^{* * *}$ \\
\hline
\end{tabular}

Note: * Spearman correlation coefficients; ${ }^{* *}$ Kruskal-Wallis test; ${ }^{* * *}$ Mann-Whitney test.

According to the Spearman correlation test, p-value at the $5 \%$ significance level, no significant difference was identified in the difference of identical stress distributions with the capillary cortisol level category. The variable, cortisol, showed an insignificant correlation with the other variables used (age, work time, professional category, and sector); i.e., the dosage of glucocorticoid in the hair was independent of the increase or decrease of the other five variables, including stress.

\section{DISCUSSION}

In the present study, data on nursing workers have similarities with those of other investigations. Most were female ${ }^{(28-30)}$ and young adults $(67.0 \%)^{(31)}$; the most prevalent professional category was nursing technician $(62.2 \%)^{(32-33)} ; 84.8 \%$ had only one job ${ }^{(28)} ; 93.9 \%$ did not have jobs in other areas than nursing, although there were still professionals who worked even in different professions in this area ${ }^{(33)}$. Regarding the work shift, 52.4\% worked during the day, and $93.9 \%$ on weekends, working 12 hours per shift for 36 hours per week ${ }^{(34)}$.

Regarding employment sectors, the participants worked in MC, ED/UC, CCU, adult ICU, and I; health professionals are exposed to factors that can trigger stress in the workplace, which are similar in several health sectors ${ }^{(35)}$. In critical care units, psychosocial elements related to mental load affect the work of nurses ${ }^{(1)}$; those who work in inpatient units tend to have average stress levels ${ }^{(7)}$; emergency workers show physiological reactions to stress, such as low back pain, fatigue, exhaustion, neck stiffness and stomach acidity ${ }^{(28)}$. Also contributing to the presence of stress are poor working conditions, low salaries, lack of professionals, and difficulties in interpersonal relationships ${ }^{(32)}$, in addition to high work demands, emotional pressure, and lack of professional recognition ${ }^{(33)}$.

The Perceived Stress Scale is a psychological tool used to measure stress perception ${ }^{(20)}$. This scale has already been administered to several Brazilian populations, such as elementary and high schoolteachers ${ }^{(36)}$, university students ${ }^{(37)}$, nursing students ${ }^{(38)}$, seniors ${ }^{(21)}$ and university teachers ${ }^{(39)}$, among others. Similarly, it has also been administered in other countries, such as women with infertility ${ }^{(40)}$ and patients with chronic headache ${ }^{(41)}$ in Iran; adults in the Republic of Cyprus $^{(42)}$; adolescents in China ${ }^{(43)}$; middle-aged and elderly women in Greece ${ }^{(44)}$; among nursing students in the Czech Republic and Slovakia ${ }^{(45)}$; hospital nurses in Jordan ${ }^{(46)}$, among others.

Capillary cortisol studies are scarcer, although hair cortisol levels are increasingly used as a measure of stress in humans and mammalian animals ${ }^{(17)}$. In the present study, capillary cortisol levels were higher than recommended. The minimum value found was $0.59 \mathrm{pg} / \mathrm{mg}$, while the maximum value was 1552.98 $\mathrm{pg} / \mathrm{mg}$. In addition, the mean capillary cortisol was $148 \mathrm{pg} / \mathrm{mg}$, and the median was $76.45 \mathrm{pg} / \mathrm{mg}$; in other words, half of the survey participants showed a capillary cortisol concentration of up to $76.45 \mathrm{pg} / \mathrm{mg}$. Similarly, in a study with capillary cortisol ${ }^{(47)}$, the result was high $(+43 \%)$ in groups with chronic stress.

However, according to the Kruskal-Wallis non-parametric hypothesis test, there was no significant difference ( $p$ value $=57.4 \%$, at $5 \%$ significance level) in identical distributions for perceived stress with the category of cortisol level.

Although cortisol is considered an important stress biomarker, and is more sensitive than the PSS, other studies related to cortisol and stress instruments also did not find statistical significance ${ }^{(12,47)}$. Findings ${ }^{(48)}$ showed that self-reported stress related to capillary cortisol was higher in the sample when the work effort was high, reward was low, and the work commitment was excessive. In a prospective association between work stress and capillary cortisol, linear regressions revealed that an increase in work stress was related to an increase in capillary cortisol ${ }^{(12)}$.

Capillary cortisol cannot always be correlated with simple stress indices, but can provide an overall assessment of chronic stress ${ }^{(14)}$. Studies with salivary cortisol also showed that perceived stress had no statistically significant effects on cortisol time trajectory throughout the day ${ }^{(49)}$.

It is necessary to discuss the work organization and conditions to which nursing professionals are exposed, and to recognize that the profession is stressful(6). The most frequent stressors are related to working conditions and personnel management ${ }^{(7)}$, in addition to devaluation of work, lack of resources, few professionals, excessive workload, short time tasks, and conflict among functions ${ }^{(6)}$. Stress among nursing staff can lead to job dissatisfaction and turnover possibilities; such problems can affect the patient care and safety (46). Valuation, motivation, and better planning of institutions are recommended factors ${ }^{(32)}$. Consequently, hiring new professionals can alleviate work overload and an increase in salary could decrease the need for other employment relationships ${ }^{(33)}$. 


\section{Study Limitation}

The limiting aspects of this study are related to the lack of a control group, and the sample of professionals being restricted to a single hospital in a city within the interior of São Paulo state. Another aspect refers to the fact that the hair samples in the laboratory were cut, because there are possibilities that the sprayed samples contain statistically higher cortisol concentrations when compared to those that were only perforated ${ }^{(26)}$. In addition, different research groups have used different methodologies for the measurement of GC, making it difficult to compare results ${ }^{(50)}$. There are also gaps regarding data collection protocols, extraction, and evaluation of hair cortisol, as well as an estimated standard value for its concentration in healthy individuals ${ }^{(26)}$.

Regarding the perception of stress through the instrument used, this research was conducted in a single hospital in the interior of São Paulo state, which limited the findings to this specific group of professionals. The fact that no statistical significance was found between the PSS data and the capillary cortisol concentrations possibly occurred due to an insufficient sample of participants. Other aspects that have not been researched, and that can be corrected in future studies, such as asking workers questions about whether or not they have had hair treatments, and whether they have used anti-inflammatory or hormonal medications.

\section{Contributions to the area}

The contributions to advances in knowledge are related to the very method used in the investigation, which was not identified in national studies in which nursing workers and capillary cortisol were addressed. It was also found that stress is present among nursing professionals, and can affect their work, the care provided, and their personal life.

\section{CONCLUSION}

Capillary cortisol levels and the PSS administered to the nursing staff indicated the presence of stress, but there was no association between these measures; however, these levels were above those recommended in most of the professionals studied.

More studies related to the measurement of cortisol in the hair of nursing professionals can be done, using other recommended laboratory methods, as well as using other stress measurement instruments. It is a priority that employers introduce changes in the work environment of these professionals, recognizing the importance and complexity of their work, and providing them with adequate working conditions.

\section{FUNDING}

This study was performed with support from the Coordenação de Aperfeiçoamento de Pessoal de Nível Superior - Brazil (CAPES) - Financing Code 001

\section{ACKNOWLEDGMENT}

The institution where the research was conducted and the hospital nursing staff who provided the material for the study.

\section{REFERENCES}

1. Vásquez PC, González GR, Fernaud EH, Cabrera DD, Klijn TP, Moreno MB. Fatores psicossociais e carga mental de trabalho: uma realidade percebida pelos enfermeiros em Unidades de Terapia Intensiva. Rev Latino-Am Enfermagem. 2015;23(2):315-22. doi: 10.1590/0104-1169.0044.2557

2. Giordani JN, Bisogno SBC, Silva LAA. Percepção dos enfermeiros frente às atividades gerenciais na assistência ao usuário. Acta Paul Enferm. 2012;25(4):511-516. doi: 10.1590/S0103-21002012000400005

3. Guido LA, Goulart CT, Silva RM, Lopes LFD, Ferreira EM. Estresse e Burnout entre residentes multiprofissionais. Rev Latino-Am Enfermagem. 2012;20(6):[08 telas]. doi: 10.1590/S0104-11692012000600008

4. Kotekewis K, Ribeiro RP, Ribeiro BGA, Martins JT. Doenças crônicas não transmissíveis e o estresse dos trabalhadores de enfermagem de bloco cirúrgico. Rev Enferm Global. 2017;46:305-14. doi: 10.6018/eglobal.16.2.252581

5. Lorenz VR, Benatti MCC, Sabino MO. Burnout e estresse em enfermeiros de um hospital universitário de alta complexidade. Rev Latino-Am Enfermagem [Internet]. 2010 [cited 2019 Jan 11];18(6):[08 telas]. Available from: http://www.scielo.br/pdf/rlae/v18n6/pt_07

6. Santana JS, Lima da Silva JL, Mello GM. et al. Instrumento de avaliação do estresse na equipe de enfermagem. Rev Atenc Saúde. 2017;15(52):61-5. doi: 10.13037/ras.vol15n52.4424

7. Simonetti SH, Bianchi ERF. Estresse do enfermeiro que atua em unidade de internação. Rev Enferm UFPE. 2016;10(12):4539-46. doi: 10.5205/ reuol.9978-88449-6-ED1012201615

8. Walvekar SS, Ambekar JG, Devaranavadagi BB. Study on Serum Cortisol and Perceived Stress Scale in the Police Constables. J Clin Diag Res. 2015;9(2):BC10-BC14. doi: 10.7860/JCDR/2015/12015.5576

9. Neumann A, Direk N, Crawford AA, Mirza S, Adams H, Bolton J, et al. The low single nucleotide polymorphism heritability of plasma and saliva cortisol levels. Psychoneuroendocrinol. 2017;85: 88-95. doi: 10.1016/j.psyneuen.2017.08.011

10. Kirou KA, Boumpas DT. Chapter 48: Systemic Glucocorticoid Therapy in SLE. In: Dubois' Lupus Erythematosus and Related Syndromes, 8th Edition; 2013. p. 591-600.

11. West DWD, Phillips SM. Associations of exercise-induced hormone profiles and gains in strength and hypertrophy in a large cohort after weight training. Eur J Appl Physiol. 2012;112(7):2693-702. doi: 10.1007/s00421-011-2246-z 
12. Herr RM, Almer C, Loerbroks A, Barrech A, Elfantel I, Siegrist J. et al. Associations of work stress with hair cortisol concentrations: initial findings from a prospective study. Psychoneuroendocrinol 2018;89:134-7. doi: 10.1016/j.psyneuen.2018.01.011

13. Meyer JS, Novak MA. Minireview: Hair Cortisol: a novel biomarker of hypothalamic-pituitary-adrenocortical activity. Endocrinol 2012;153(9):4120-7. doi: 10.1210/en.2012-1226

14. O'Brien KM, Tronick EZ, Moore CL. Relationship between Hair Cortisol and Perceived Chronic Stress in a Diverse Sample. Stress Health 2012;29(4):337-44. doi: 10.1002/smi.2475

15. Manenschijn L, Koper JW, Lamberts SW, van Rossum EF. Evaluation of a method to measure long term cortisol levels. Steroids. 2011 [cited 2019 Jan 11];76(10-11):1032-6. Available from: https://www.ncbi.nlm.nih.gov/pubmed/21515299

16. Russell E, Koren G, Rieder M, Van Uum S. Hair cortisol as a biological marker of chronic stress: current status, future directions and unanswered questions. Psychoneuroendocrinol. 2012;37(5):589-601. doi: 10.1016/j.psyneuen.2011.09.009

17. Binz TM, Braun U, Baumgartner MR, Kraemer T. Development of an LC-MS/MS method for the determination of endogenous cortisol in hair using 13C3-labeled cortisol as surrogate analyte. J Chromatography B. 2016;(1033-1034):65-72. Doi: org/10.1016/j.jchromb.2016.07.041

18. Bussab WO, Morettin PA. Estatística Básica. 4.ed. São Paulo: Atual;1987.

19. Dalri RCMB. Carga horária de trabalho dos enfermeiros de emergência e sua relação com estresse e cortisol salivar [Tese]. Escola de Enfermagem de Ribeirão Preto da Universidade de São Paulo, São Paulo;2013. doi: 10.11606/T.22.2013.tde-07012014-161525

20. Cohen S, Kamarck T, Mermelstein R. A Global Measure of Perceived Stress. J Health Soc Behavior [Internet] 1983 [cited 2019 Jan 11];24(4):385-396. Available from: http://www.psy.cmu.edu/ scohen/globalmeas83.pdf

21. Luft DCB, Sanches SO, Mazo GZ, Andrade A. Versão Brasileira da Escala de Estresse Percebido: tradução e validação para idosos. Rev Saúde Pública. 2007;41(4):606-15. doi: 10.1590/S0034-89102007000400015

22. Faro A. Análise Fatorial Confirmatória das Três Versões da Perceived Stress Scale (PSS):Um Estudo Populacional. Psicol. Reflex. Crit. 2015;28(1):21-30. doi: 10.1590/1678-7153.201528103

23. Da Silva AMB;Enumo SRF. Estresse em um fio de cabelo: revisão sistemática sobre cortisol capilar. Aval Psicol. 2014;13(2):203-11. Available from: http://pepsic.bvsalud.org/scielo.php?script=sci_arttext\&pid=S167704712014000200008\&lng=pt

24. Rocky Mountain Analytics. Hair Cortisol. Clinical Information for Professionals[Internet], 2014 [cited 2019 Jan 11]. Available from: http:// rmalab.com/medical-laboratory-tests/hormone/hair_cortisol

25. Gow R, Thomson S, Rieder M, Van Uum S, Koren G. An assessment of cortisol analysis in hair and its clinical applications. Forensic Sci Int [Internet]. 2010 [cited 2019 Jan 11];196(1-3):32-7. Available from: https://www.ncbi.nlm.nih.gov/pubmed/20096513

26. Paza DLS, Pierozan GC, Furyama GY, Stefanello JMF. Cortisol capilar como medida de análise do estresse crônico. Psic Saúde Doenças. 2017;18(3):773-88. doi: 10.15309/17psd180312

27. Goldberg SB, Manley AR, Smith SS, Greeson JM, Russell E, Uum SV, et al. Hair Cortisol as a Biomarker of Stress in Mindfulness Training for Smokers. J Altern Complement Med [Internet]. 2014 [cited 2019 Jan 11];20(8):630-4. Available from: https://www.ncbi.nlm.nih.gov/pmc/articles/PMC4129663/

28. Dalri RCMB, Silva LA, Mendes AMOC, Robazzi MLCC. Carga horária de trabalho dos enfermeiros e sua relação com as reações fisiológicas do estresse. Rev Latino-Am Enfermagem. 2014;22(6):959-65. doi: 10.1590/0104-1169.3292.2503

29. Ribeiro RP, Marziale MHP, Martins JT, Ribeiro PHV, Robazzi MLCC, Dalmas JC. Prevalência da Síndrome Metabólica entre trabalhadores de Enfermagem e associação com estresse ocupacional, ansiedade e depressão. Rev Latino-Am Enfermagem. 2015;23(3):435-40. doi: 10.1590/0104-1169.0383.2573

30. Luan X, Wang P, Hou W, Chen L, Lou F. Job stress and burnout: A comparative study of senior and head nurses in China. Nurs Health Sci. 2017;19(2):163-9. doi: 10.1111/nhs.12328

31. Watanabe N, Furukawa TA, Horikoshi M. et al. A mindfulness-based stress management program and treatment with omega-3 fatty acids to maintain a healthy mental state in hospital nurses (Happy Nurse Project): study protocol for a randomized controlled trial. Trials. 2015;16(36);1-12. doi: 10.1186/s13063-015-0554-z

32. Souza NR, Bernardes EH, Fonseca RP, Gonçalves HO, Lopes TFS. Identificando o Nível de estresse e suas causas nos profissionais de enfermagem em um hospital geral de Passos (MG). Rev Ciênc Praxis [Internet]. 2009 [cited 2019 Jan 11];2(4):27-32. Available from: http:// revista.uemg.br/index.php/praxys/article/view/2096/1089

33. Ueno LGS, Bobroff MCC, Martins JT. Estresse Ocupacional: Estressores Referidos Pela Equipe de Enfermagem. Rev Enf. UFPE. 2017;11(4);1632-8. doi: 10.5205/reuol.9763-85423-1-SM.1104201710

34. Simões JS, Otani MAP, Siqueira Jr AC. Estresse dos Profissionais de Enfermagem em uma Unidade de Urgência. REGRAD, UNIVEM [Internet]. 2015 [cited 2019 Jan 11];8(1):75-95. Available from: http://revista.univem.edu.br/REGRAD/article/view/862/403

35. Oliveira RJ, Cunha T. Estresse do Profissional de Saúde no Ambiente de Trabalho: Causas e Consequências. Cad Saúde Desenvolv [Internet]. 2014 [cited 2019 Jan 11];3(2):78-93. Available from: https://www.uninter.com/revistasaude/index.php/cadernosaudedesenvolvimento/ article/download/302/28

36. Machado WL, Damásio BF, Borsa JC, Silva PJ. Dimensionalidade da escala de estresse percebido (Perceived Stress Scale, PSS-10) em uma amostra de professores. Psicol Reflex Crít. 2014;27(1):38-43. doi: 10.1590/\$0102-79722014000100005

37. Dias JCR, Silva WR, Maroco J, Campos JADB. Escala de estresse percebido aplicada a estudantes universitárias: Estudo de validação. Psychology, Commun Health [Internet]. 2015[cited 2019 Jan 11];4(1):1-13. Available from: http://hdl.handle.net/11449/126011 
38. Flauzino MM, Garcia VPT, Gonçalves LA, Correia C, Parmigiani RS, Pereira SS, et al. Percepção de estresse nos acadêmicos de enfermagem de uma instituição particular de ensino. Arch Health Invest. 2017;6(Spec Iss 4). doi: http://dx.doi.org/10.21270/archi.v6i0.2286

39. Soares MB. Escala de Estresse Percebido aplicada a Docentes da Universidade Federal de Viçosa: um estudo de validação de instrumento. XXVIII ENANGRAD [Internet]. Brasília - D.F., 2017 [cited 2019 Jan 11]. Available from: http://www.enangrad.org.br/2017/pdf/2017_ ENANGRAD219.pdf

40. Maroufizadeh S, Foroudifard F, Navid B, Ezabadi Z, Sobati B, Omani-Samani R. The Perceived Stress Scale (PSS-10) in women experiencing infertility: a reliability and validity study. Middle East Fertil Soc J [Internet]. 2018 [cited 2019 Jan 11];23(4):456-459. Available from: https:// doi.org/10.1016/j.mefs.2018.02.003

41. Khalili R, Nir MS, Ebadi A, Tavallai A, Habibi M. Validity and reliability of the Cohen 10-item Perceived Stress Scale in patients with chronic headache: Persian version. Asian J Psychiatr. 2017;26:136-140. doi: 10.1016/j.ajp.2017.01.010.

42. Michaelides MP, Christodoulou A, Kkeli N, Karekla M, Panayiotou G. Factorial structure of the perceived stress scale and implications for scoring. Rev Européenne Psychol Appliquée 2016;66(6):309-16. doi: 10.1016/j.erap.2016.07.002

43. Liu QQ, Zhang DJ, Yang XJ, Zhang CY, Fan CY, Zhou ZK. Perceived stress and mobile phone addiction in Chinese adolescents: a moderated mediation model. Comp Human Behavior. 2018;87:247-53. doi: 10.1016/j.chb.2018.06.006

44. Nigdelis MP, Martínez-Domínguez SJ, Goulis DG, Pérez-López FR. Effect of programmed exercise on perceived stress in middle-aged and old women: A meta-analysis of randomized trials. Maturitas 2018;114:1-8. doi: 10.1016/j.maturitas.2018.05.004

45. Gurková E, Zeleníková R. Nursing students' perceived stress, coping strategies, health and supervisory approaches in clinical practice: a Slovak and Czech perspective. Nurse Educ Today 2018;65: 4-10. doi: 10.1016/j.nedt.2018.02.023

46. Masa'Deh R, Alhalaiqa F, AbuRuz ME, Al-Dweik G, Al-Akash HY. Perceived Stress in Nurses: a Comparative Study. Global J Health Science [Internet]. 2017 [cited 2019 Jan 11];9(6). Available from: https://www.researchgate.net/ publication/311900028_Perceived_Stress_in_Nurses_A_Comparative_Study

47. Stalder T, Steudte-Schmiedgena S, Alexander N, Klucken T, Vater A, Wichmann S, et al. Stress-related and basic determinants of hair cortisol in humans: a meta-analysis. Psychoneuroendocrinol; 2016;77:261-74. doi: 10.1016/j.psyneuen.2016.12.017

48. Meij LVD, Gubbels N, Schaveling J, Almela M, Vugt MV. Hair cortisol and work stress: Importance of workload and stress model (JDCS or ERI). Psychoneuroendocrinol. 2018;89:78-85. doi: 10.1016/j.psyneuen.2017.12.020

49. Mikkelsen S, Forman JL, Fink S, Vammen MA, Thomsen JF, Grynderup MB. et al. Prolonged perceived stress and saliva cortisol in a large cohort of Danish public service employees: cross-sectional and longitudinal associations. Int Arch Occup Environ Health. 2017;90(8):835-48. doi: 10.1007/s00420-017-1241-z

50. Albar WF, Russell EW, Koren G, Rieder MJ, Van umm SH. Human hair cortisol analysis: comparison of the internationally-reported ELISA methods. Clin Invest Med [Internet]. 2013 [cited 2019 Jan 11];36 (6):E312-E316. Available from: https://pdfs.semanticscholar.org/93a5/ c9458e7a25210eddf35558899e6da8fbcb19.pdf 